\title{
Under a Blue Sky - Part 1
}

Participation and Mourning in Cambodia, an Autobiographical Approach

\section{Ella Pugliese}

\section{(2) OpenEdition}

\section{Journals}

Electronic version

URL: http://journals.openedition.org/anthrovision/1492

DOI: 10.4000/anthrovision. 1492

ISSN: 2198-6754

\section{Publisher}

VANEASA - Visual Anthropology Network of European Association of Social Anthropologists

\section{Electronic reference}

Ella Pugliese, «Under a Blue Sky - Part 1 », Anthrovision [Online], 3.1 | 2015, Online since 23 November 2015, connection on 30 April 2019. URL : http://journals.openedition.org/anthrovision/1492 ; DOI : 10.4000/anthrovision. 1492

This text was automatically generated on 30 April 2019.

(c) Anthrovision 


\section{Under a Blue Sky - Part 1}

Participation and Mourning in Cambodia, an Autobiographical Approach

\section{Ella Pugliese}

Anthropology that doesn't break your heart is not worth doing Behar 1996: 177

Cambodian sky

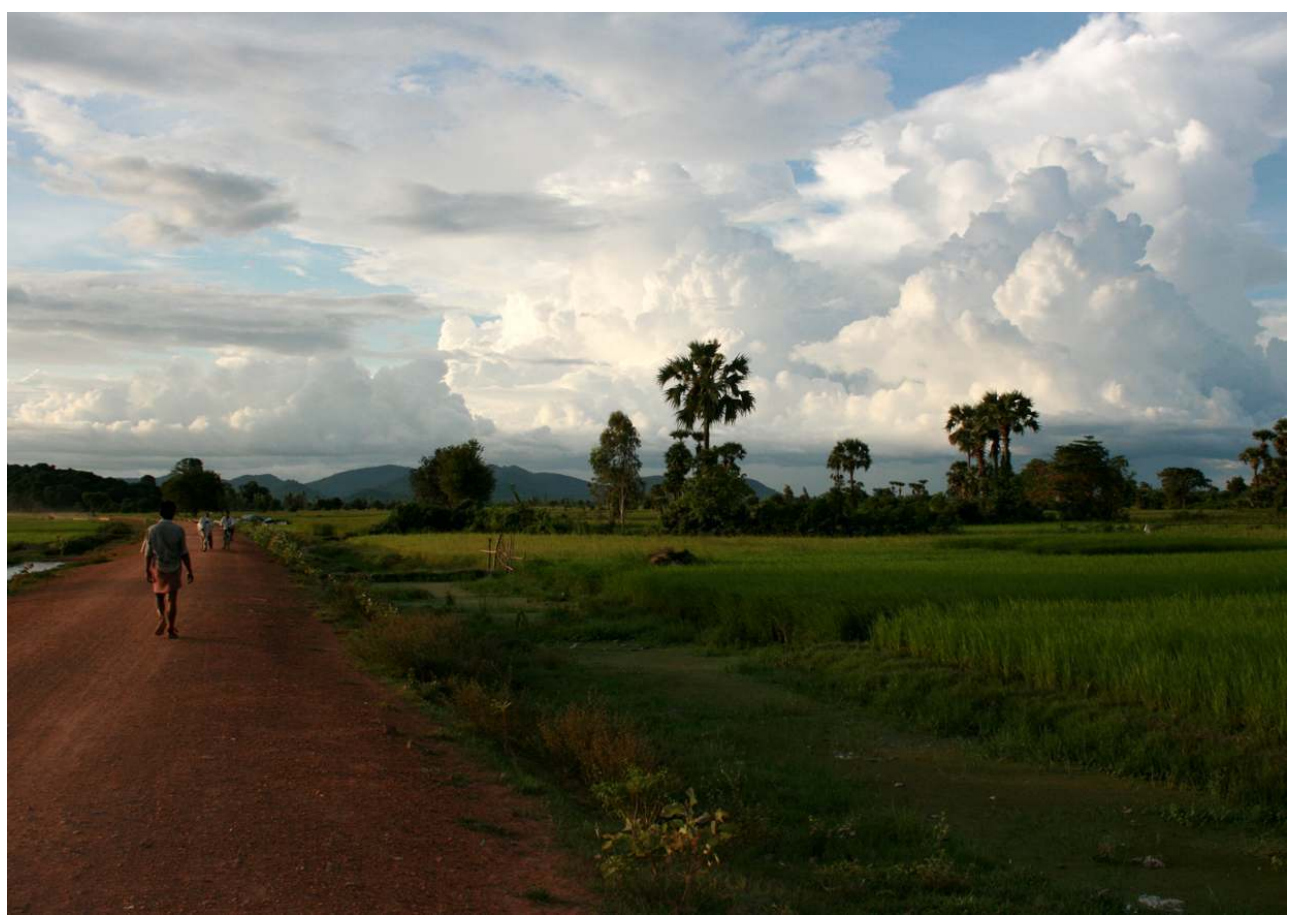

photo by Leah Roth Howe, 2008 


\section{Introduction}

1 Jens Joester, my beloved partner and father of my daughter, died in an accident in Cambodia in 2009. He had been the main cameraman, editor and graphic designer of the film we had gone there together to make: We Want (U) to Know, a documentary about loss, death, mourning, surviving the Khmer Rouge Regime, and coping with the past 30 years later.

2 This article combines reflection, reportage, and poetry about how my experience of Jens' death affected my understanding of the nature and value of our work in Cambodia, and how the process we had been through together had already shaped my perception of death. Jens' sudden departure turned my life completely upside down, I felt desperate, lost, abandoned, lonely. But I had our daughter. And I had this film. The experiences we had all shared in Cambodia and the meaning of our work there together gave me strength. I kept working on We Want (U) to Know, and travelled around to screen it. But I kept my own trauma private and separate from the stories told in the film.

3 In 2012 I returned to the places where we had lived and worked together before. As I met the people we had been working with for the first time since Jens' death - the protagonists of our film, old villagers who had faced the horror of mass death and survived - I began to perceive my personal tragedy in a new light. I realized that my relationship to the film had changed, and at the very moment of Jens' death. After the first years of intense mourning, with the apparently typical succession between moments of lucidity and waves of hopeless sorrow, now, as I faced the smiles of the old survivors, I felt the urge to 'come out' with my own story.

4 I began to write, trying to untie the knots on multiple levels - the private and the public, the personal and the collective, work and life, the western and Cambodian perspectives, the religious aspects, and so on. It was clear from the start that this was going to be a hybrid piece, moving from autobiographic storytelling to anthropological investigation. Poetry, an old and trusted companion emerged as it always had in difficult times during my life, and gave me (and the text) another level - eventually the most intimate, irrational and courageous voice in the text. Next to the poems I used photos and drawings, not only to give faces to names and places but also to explore some of the more elusive threads of this story that I can only begin to express in words: a poetical use of pictures which works through association and evocation rather than explanation. Sometimes the photos show a particular situation, and sometimes they evoke something abstract and invisible, inviting readers to make their own journey to seek, establish, and create their own connections. "Because a successful narrative or lyric poem can echo or resonate so powerfully with the emotional experience and sense of identity of cultural insiders, it allows us to see the nuances and complexities of culture. (...) Poetry and culture brim with indirection, ambiguity, lacunae, indeed, with downright silence." (Maynard and Cahnmann 2010: 6) ${ }^{1}$.

5 This paper has accompanied me in its core draft since then, and after many years and another trip back to Cambodia, it is on its way to becoming a new film, but that is still in the future. 


\section{The Back Story}

6 Between October 2008 and May 2009 we had been working with survivors of the Khmer Rouge Regime in a beautiful village in the countryside and in Phnom Penh, using film and art as tools to cope with the tremendous past. It was the first period of the ongoing Khmer Rouge Trials of the last living leaders. Over 30 years since the fall of the Khmer Rouge, a new discourse about the past was beginning in the civil society ${ }^{2}$. Local and international NGOs were initiating new projects to introduce public discussions about the Khmer Rouge Regime throughout the country. But they were also seriously afraid of the possible reactions, such as outbursts of rage and the escalation of local conflicts, and the risk of general re-traumatization. In the countryside in particular, victims and perpetrators had already achieved a delicate system of co-existence, based on Buddhist beliefs and the acceptance of their own destinies. Along with the high expectations produced by the legal process, critical voices were being heard in public media about its likely controversial impact on the daily life of Cambodians.

7 The participatory approach ${ }^{3}$ of our film was conceived in the context of NGO outreach to initiate a community process that respected the needs of the protagonists as much as possible, given the specific moment and the specific group of people that we, the film crew, were. Our approach was influenced by dominant western categories:

"The accounts given in many areas of the Tribunal have tended to impose an overall pattern of what social suffering should be and how it should be expressed and relieved, by using the idioms of 'trauma' and 'post-traumatic stress disorder' as their only models." ${ }^{4}$

8 We were looking for alternatives within this dominant discourse and trying to develop them in interaction with our target group of Khmer Rouge survivors. It was the idea and wish of the villagers who actively participated in our project to re-enact the killings and the cruelties of the past. Without having much confidence in trauma theories, I felt that 'going through' what had happened to them 30 years ago, in a safe warm setting, was a courageous choice that should be supported. With Jens and the film crew we were working with older men and women who lost their beloved ones in highly traumatic ways. We were going back to the places where all this had happened, and together we were reconstructing the moments in which the husbands (mostly) had been taken away and eventually killed. Throughout the project we shared very intense and emotional experiences; we cried and laughed together, we created some special bonds.

On 7 May 2009 we presented the first version of We Want (U) to Know to a wide public. The huge Chenla Theatre in Phnom Penh was almost full, and ten villagers were our special guests. One week later Jens fell off a bridge and died. And I left after a few days with our daughter - in shock ${ }^{5}$.

10 In April 2012, I was able to return with the same film crew, the psychologists, and the little one to Thnol Lok, the village in which $W W U 2 K^{6}$ takes place. We went there to show the film in its final version and make a follow up of the project. Was it really as good as we believed at the time? What did it leave there? What would the reactions be three years later?

11 An unexpected element in the follow-up process emerged over the others though. Through the personal connection that I felt with our protagonists ${ }^{7}$, especially the old women and the young men who had been working closely with Jens who taught them 
how to handle the camera, we had become friends. So what would it be like for me to go back there again? Knowing what had happened, how would people react to seeing me and our daughter three years later?

The parallels and intersections between work and life in my case are so strong that sometimes I lose myself trying to understand them. Back in Thnol Lok I decided to film, and I was filming as I went back for the first time to the place where Jens had died. I was using the camera as a third eye and as a defence between the word and me, between the country where my life drastically changed and me.

The words I use now sound very much like the words we used in WWU2K about Grandma Nhey, one of the main characters, and her decision to go back to the pagoda where her husband had been taken away in the 70s in order to film right there.

14 I already felt a strong discrepancy growing in myself when I presented WWU2K at film festivals and conferences, in universities and schools, because I discussed the process we went through in Cambodia with very interested viewers without going public, without a word about this private story. I was recounting what I had experienced and learned, what I had observed and shared with the villagers of Thnol Lok about loss and mourning, with no regard for my own desperate search for meaning and relief.

15 I started to ask myself what if any possible lessons could be drawn from this tragic and surreal story: going deep into post-traumatic scenarios and, as a curious furious existential joke, ending up being broken and traumatized as well.

\section{Situating Myself ${ }^{8}$}

16 I am not an anthropologist, I am a filmmaker - or the other way around: I make documentary films with an anthropological focus. At least that's what people have been saying about my work from the very start, and what the list of ethnographic film festivals and conferences I have been involved with in the past 10 years implies.

17 What is this anthropological focus all about? A certain regard, an interest in the 'Other', a longing to understand other cultures in the broadest sense. At a young age I used to write and read poems in pubs and metro stations, and saw the pen as my pencil to draw reality. It was during those years that I got my hands on a camera almost by chance, and discovered the evocative power of the third eye. This was the perfect instrument to translate my eagerness for the world outside and my growing passion for travelling into a precise tool for disclosure and interpretation. It followed a series of workshops and courses, but I consider my training to have been a classical 'learning by doing' process which started in the context of audio-visual anthropology ${ }^{9}$ and continued through collaborations with filmmakers of many different origins and backgrounds.

From the very beginning I was fascinated by the effects of the camera's presence on reality. In each project I became more and more aware of the interaction between myself behind the camera and the protagonists on the other side, and how the third eye influences actions and thoughts. I never believed in any kind of objectivity in my documentary making. I have always believed in the beauty and poetry of the pictures that translate our emotions. Films can touch somewhere deep inside, open up our imagination and connect us with something very near to the truth of life - if any such thing exists. 
19 By reading these lines you may have already forgotten that the main subject of this article is my own broken life, broken in the context of my own filmmaking. Every time I reread this passage I have to smile: how could the reader have already forgotten it? Nevertheless, it seems as if my writing moves back and forth between introspection and storytelling, growing closer to my personal experience of loss only to become removed in the next chapter or paragraph and then becoming closer again in the next one. It seems to me that my writing itself forgets, remembers, and forgets again, as if closeness and distance are both necessary to write, to tell and to remember.

\section{Situating We Want $(U)$ to Know: the Participatory Approach}

WWU2K was realized in co-operation between three Cambodian NGOs, the Khmer Institute of Democracy (KID), the International Center for Conciliation (ICfC Cambodia, now Kdei Karuna), and the Transcultural Psychological Organization (TPO), funded by the German Development Agency (now GIZ) within the framework of its civil peace service program of 2008 , with an implementation time of seven months, and three locations ${ }^{10}$.

21 By 2008 the participatory observation of my previous projects was turning into a much more inclusive approach. Whenever I have been asked by the TPO psychiatrists whether I could imagine that making a film could become an instrument of work for the Cambodian civil society to promote reconciliation in the aftermath of the Khmer Rouge, my immediate reaction has been: only if we work in participation with the Cambodians who may benefit from it.

"Participatory documentary involves groups or individuals who would traditionally be the subjects of others' research in taking and interpreting their own film in order to address and share important aspects of their lives and experiences. It seeks to alter the constructs of traditional qualitative research enquiry in which 'outsider' researchers investigate and assess the lives of 'insider' research subjects. Participatory Video (short: PV) methods value local knowledge, build bridges between communities and decision-makers and enable people to get greater control over their own development and the decisions affecting their lives. It hands over control to the target communities from project conception through to implementation, monitoring and evaluation." ${ }^{11}$

22 At the time we defined WWU2K as 'Participatory Video'. Today I am more cautious with terms, because I have had the chance to test the limit of this method in own projects and those of others ${ }^{12}$. In particular its major ambition, to change the roles of the different people involved and opt for a more equalitarian decision-making process, has to be rigorously demonstrated. The determining questions are: Who originated the project concepts, and why? Where are the funds coming from? How transparent and free is the participation process? Does the project answer a real need within the target group? Can you speak of a community or a village as one homogeneous subject? What about community or village members who choose not to participate? These are only some of the problematic aspects of PV that can become weaknesses during a project unless they are explicitly identified and acted on.

Nonetheless, I appreciate the concept of sharing and going together through a process with initial ideas that will change and grow through the inputs of the participants. But it is essential to stay honest and acknowledge the different positions of power that 
everybody takes during the project, as well as the real motivations and needs of all participants. I believe that it is possible to open up, to share at least part of the given power, to learn from each other, and to go through changes together, which then may potentially change everybody involved.

Today PV is very 'in'. Although I consider it to be an approximation of terms, the label 'Participatory Video' is helpful to give a quick idea of the open orientation you may want to bring to your approach. But when possible I prefer to use the word 'inclusion' instead, as inclusion is an action that somebody is doing towards somebody else, so there is more transparency in the responsibilities, which is essential for understanding the results accurately.

Concerning WWU2K, I realized in retrospect that I was basically 'including' the people I was working with in the different stages and level of filmmaking. I started including my main collaborator, my Cambodian colleague Nou Va, in the directorial processes, so that he became, with much pushing from my side and hesitation from his, my co-director. Nou Va and I asked the villagers who should become our protagonists to take part actively in the film from the ideation process, so we became a big film crew, with those more interested in filming starting to work side by side with Jens ${ }^{13}$, and others ideating and directing the scenes on the 'set' which they had created. A few acted themselves or their family relatives. Some just drew and painted the scenes that others would re-enact. None of the villagers was interested in the editing process, so we later included personalities from Cambodian civil society and other filmmakers in the process of post-production in Phnom Penh through open screenings and discussions.

Our 'cameraman to be', the young Kakkda

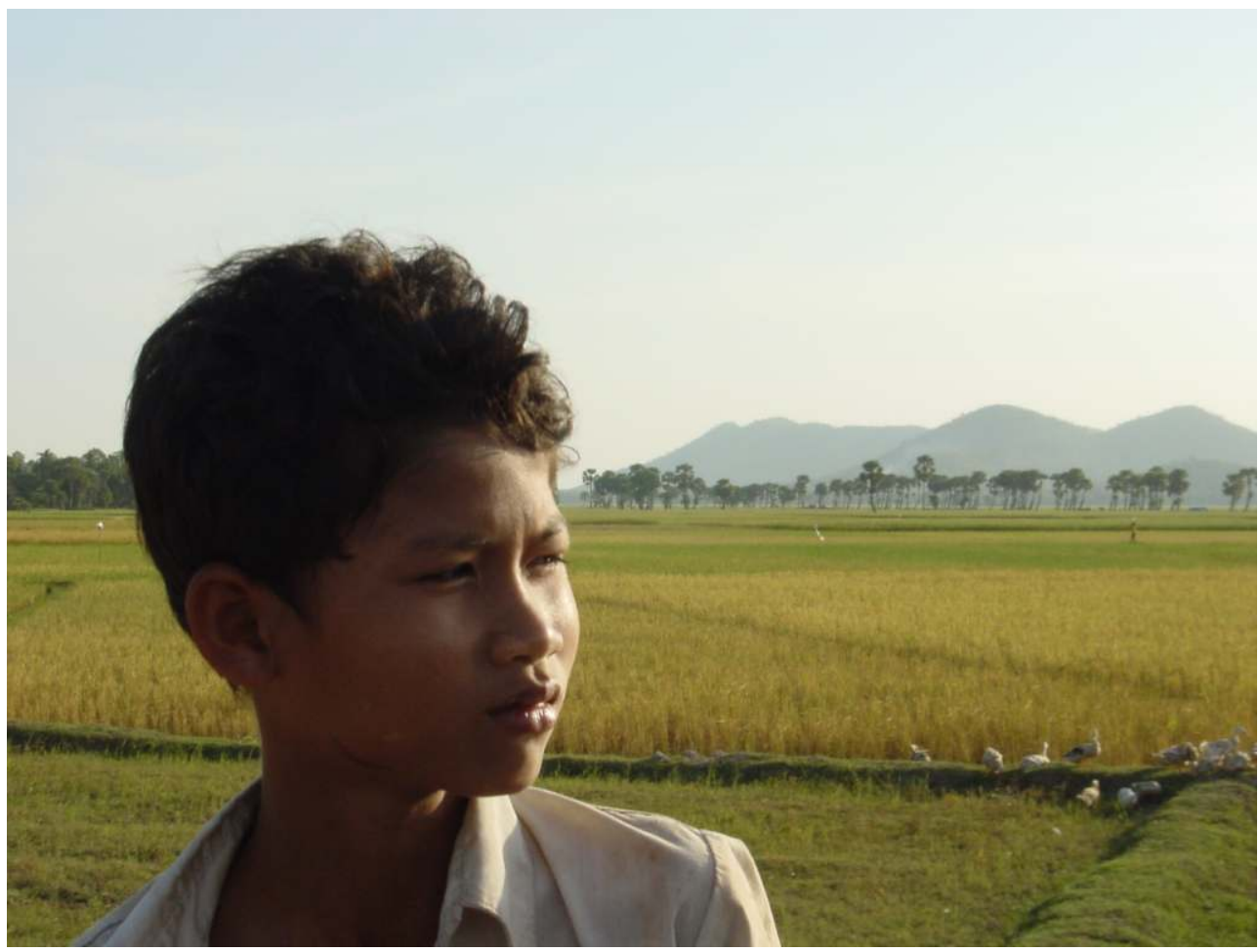

Photo by Julian Poluda (2008) 
26 And it was an amazing process. When 'our' protagonists, as I like to call the people who
were invited to participate in the project and accepted the challenge, it soon became clear
to us, the internationals, the Cambodian staff from Phnom Penh and the village
cameramen, that we literally had to run behind the villagers; they were acting out their
past, while we were trying to understand what was going on. I liked the fact that the
process took its own path, and that the villagers took the initiative so enthusiastically
that at first we almost couldn't follow.

In PV a sensitive question arises concerning the ethical and philosophical aspects of ethnography and filmmaking. Is there a shift of responsibility in this tendency of PV to share decisions and roles? This was a possibility that we need to keep in mind in the field, but I don't think that there is an absolute answer to it. In the case of WWU2K we genuinely believed in the ability of the villagers to guide us where it was important to them to go. We believed in the process we all were part of, and maybe it was also our naivety that made it so powerful - and so successful ${ }^{14}$.

\section{Villagers taken away by Red Khmer soldiers}

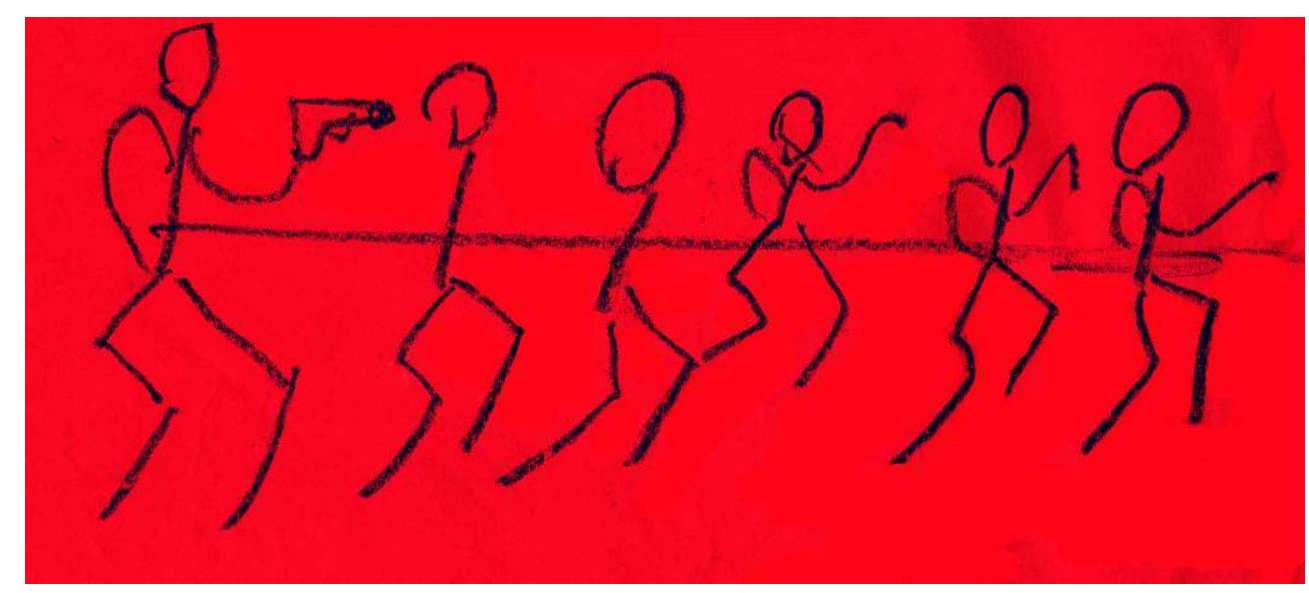

Storyboard drawing for the collective deportation scene.

Drawing by the villagers of Thnol Lok (2008)

It went more or less like this. In the first week, while we were explaining our presence there and our goals, some villagers 'answered' by asking if they could reconstruct and reenact the 'crimes of the Khmer Rouge time' together. We were initially sceptical about the possibility of doing this without any material resources. As they insisted, we had to give it a try. We proposed meeting in the Phnom Plet pagoda, which often hosted us from then on, and we started to draw the scenes to prepare some kind of storyboard. Not only did we come out with impressive drawings and intense moment of exchange. After the drawing session, the villagers transformed the pagoda in the back stage of the first reconstruction scene, surprising everyone by organizing the set autonomously. Some were explaining the scene with the related drawing and establishing the roles. Others were looking for the costumes. One man spontaneously offered his black trousers (which he took off, to the hilarity of many): others offered caps, and some looked around for the red $k r o m a^{15}$. And of course we were not just there staring at them. We were part of it, giving tips, filming, trying to understand. It was a loud, enthusiastic, funny event. We were almost embarrassed by so much laughter as we prepared an execution scene, but of 
course, we could not resist it, and we all knew that this moment of sharing was an act of exorcism and catharsis within the safe, sacred walls of the pagoda. Again, 'we' means here the 'non-villagers', the externals, the outsiders intruders invaders... Internationals and Cambodians, those who brought the cameras, those who brought the idea of a film at first, those with the power in some sense, but with the mission to give up, or at least share this power, surprised and delighted to see how this would work out. I wouldn't say that it worked completely, but it did to some extent.

This media file cannot be displayed. Please refer to the online document http:// journals.openedition.org/anthrovision/1492

Link: https://player.vimeo.com/video/141045676

Video extract by Ella Pugliese (2015) from We Want (U) To Know by Ella Pugliese, Nou Va and the villagers (2009)

This very first moment in the pagoda encapsulates for me the core of our work there for the days and scenes that followed. I would almost dare to call it 'emotional interaction' which is good for the heart and which alleviates the sorrow, at least temporarily.

At the time I was not especially aware of the cultural differences that emerge if you talk about trauma. "To be traumatized is precisely to be possessed by an image or event", writes Cathy Caruth. "The traumatized (...) carry an impossible history with them, or they become themselves the symptom of a history that they cannot entirely possess." (1995: $4-5)^{16}$. It is very difficult to take a position within the debate about how and if the western concept of trauma should be exported or translated to other contexts, but I like Caruth's definition very much and I have the impression that this may apply to some of the Khmer Rouge survivors I met, although they themselves wouldn't call it 'trauma' ${ }^{17}$. Trauma is a western concept that cannot be found in Khmer language. The closest concept is baksbaat, 'broken courage', but this is culturally specific and contextual ${ }^{18}$. On the one hand the approach of WWU2K was mostly shaped by the background of we Internationals ${ }^{19}$; on the other our Cambodian colleagues, especially the TPO psychologists, had their own perceptions of the ongoing suffering, and related to the survivors in more appropriate and culturally sensitive ways. From my point of view, my work as filmmaker was based on and intersected with the experiences and knowledge of my colleagues already engaged in the field ${ }^{20}$. Through this richness we, as a film and project crew, were able to relate to our protagonists' needs in a fairly open and fluid way, so I believe that the results do fall outside any simple schematic pattern. 


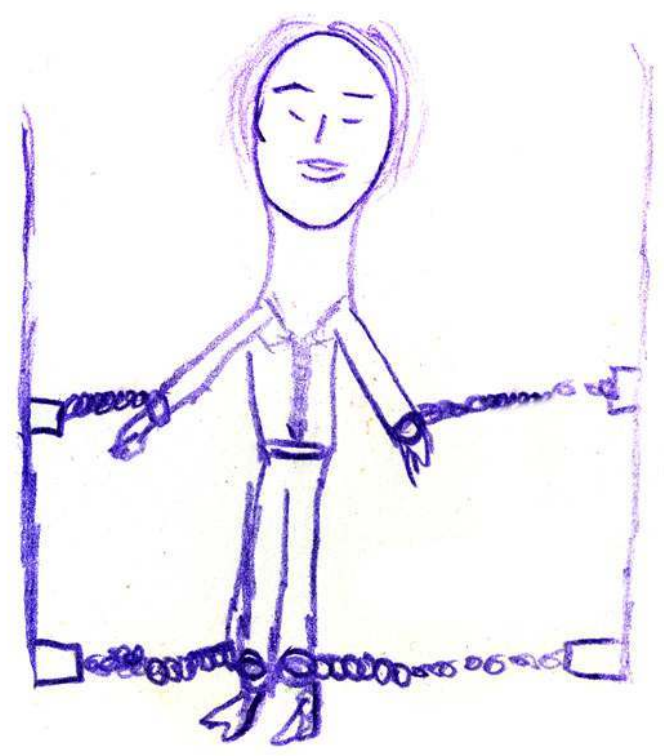

Drawing by the villagers of Thnol Lok (2008)

The first scene that we filmed was the one where some villagers are taken away on foot by two young Khmer Rouges to be executed in the killing fields. It was important for the villagers to follow the original path along which victims had been taken at the time, to the place where hundreds of people were killed, although today you can see only rice fields. But we did not know that. We were running behind them as they started to walk because they did not tell us the route, nor did they tell us clearly that they intended to come to the killing field and mime the execution. They just did it. As the commentary states in the film: We were astonished. We admired the gravity of their walk, the concentration of their eyes as they went -- and this after all the fun and laughter of the preparations. Of course we also asked ourselves to what extent this would bring back feeling of despair and rage, and how far it might lead to re-traumatization ${ }^{21}$. We came back to the pagoda together afterwards, feeling excited, proud and in a way lighter - I can't ascribe these emotions to the villagers, but this is how it seemed. This is how I remember that moment under the sun. 


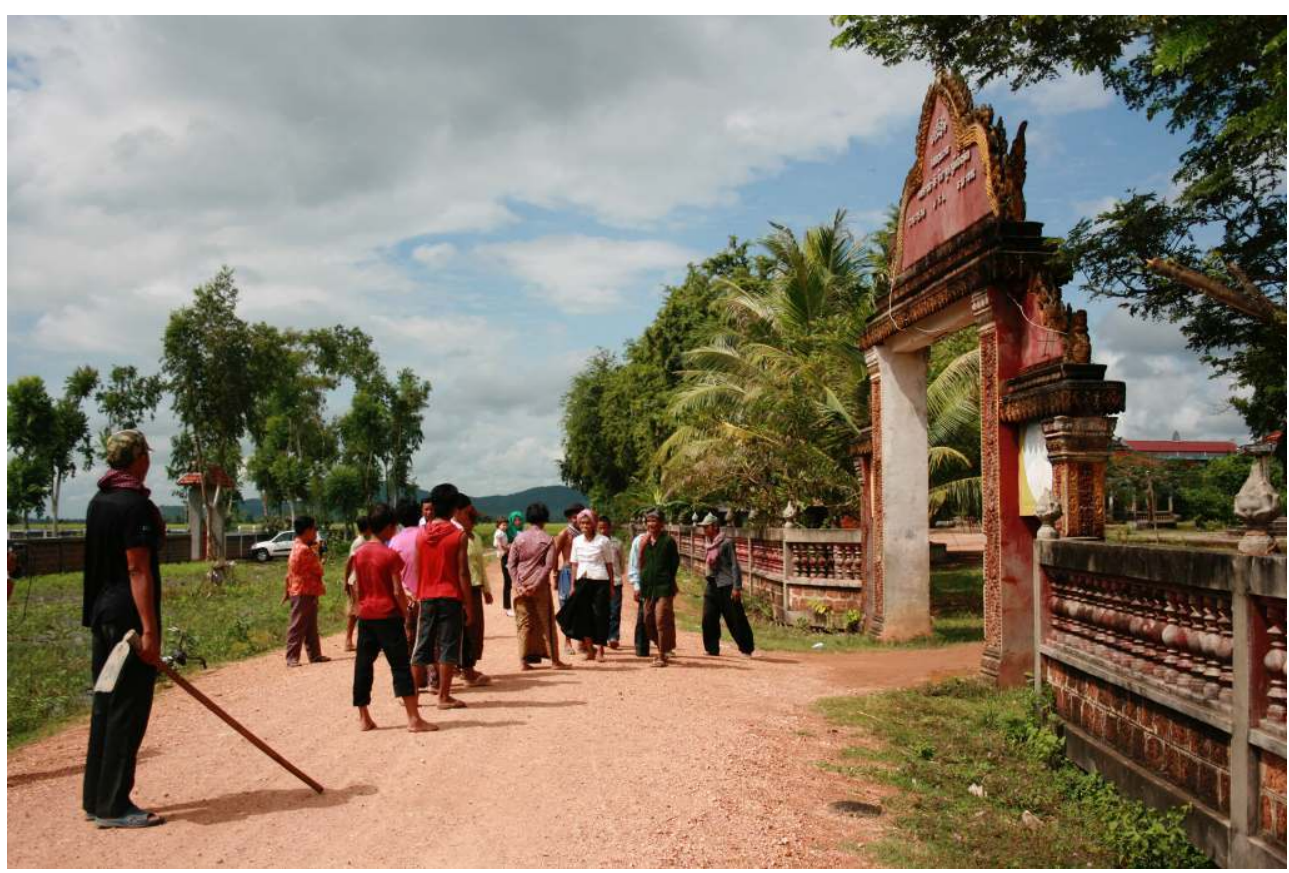

Villagers are brought to the detention centre inside the temple by Khmer Rouge soldiers in order to be executed in the nearby killing fields.

Photo by Leah Roth-Howe (2008)

Our protagonists were participating in a film about the history of their country and their own personal history. This was a history of death, loss and mourning - but also ultimately of surviving and struggling for a better life.

I could not know - nobody could know - that around the end of our work together I too would participate in their destiny of trauma and pain, under the same blue sky.

\section{Situating the 'Crisis'}

In the summer of 2012, a few months after I returned to Cambodia for the first time, I had the chance to participate in the Visual Anthropology workshop "Visualizing Crisis" in Ascona $^{22}$, where the first draft of this article was conceived. It was an incredibly hard and significant challenge for me to take a look at Jens' death as a form of 'crisis', a break in work and life, indeed a rupture in what we had been doing together, there and everywhere. The task of the workshop was to analyse how different form of crisis would influence or change the course of anthropological fieldwork as well as its meaning in the making. Every case is special and in my case the special aspects are that it was a personal tragic crisis, and that it took place not during fieldwork, but straight after.

Of course there was still much work to do with WWU2K after we presented it to the public in Phnom Penh. Although Jens's death abruptly interrupted everything, including the subsequent post-production and distribution work, during the following months and years I kept working on the film as continuously as I could ${ }^{23}$. Then in April 2012 I participated in and to some extent guided the follow-up of the project in the Cambodian 
village, well aware of my personal involvement, but less conscious of the psychological impact the journey back could have on me long after this moment.

Furthermore, in some sense this time I 'repeated' the itinerary of some of our protagonists in Cambodia: 'going through once again'. This seems to be the core of therapeutic work based on performative arts with traumatized people, such as theatre: reconstructing the traumatic past in a safe setting, in order to desacralize it, make it touchable, mitigate its danger and re-appropriate painful memories. In 2008 I had some precious talks about similar psychotherapeutic methods with the experts at TPO, who introduced me to the concepts of 'exposure' and 'testimony therapy'24. Nevertheless I was basing my intervention in the village essentially on my own understanding and intuition as filmmaker and as human being. The re-enactment of the past reminded me of the old Greek theatre, which I studied at school, with its role as collective healing ritual through catharsis $^{25}$. Three years later, as I decided to go back to the place where Jens had died, I opted for a similar approach - from a sense of unspoken urgency for the intuitive search I was starting, to take the camera with me without knowing exactly why, but feeling strongly that it would help me.

Since then I have started a process of self-reflection with the support of critical instruments from trauma theory, ethnography of loss and mourning and autoethnography (especially Behar 2003, Caruth 1995, Levine 1997, Ellis 2003, and many others $)^{26}$. I later came in contact with testimony therapy, through the precious work of Danish psychologist Inger Agger, who is currently focusing her studies on Cambodia ${ }^{27}$. One of the simplest but, indeed, to me more illuminating concept is "that grief is part of the human experience that we all have to deal with, and that the real experts are the mourners themselves". ${ }^{28}$

As in 2008 I was asked to realize a film with Cambodian survivors for Cambodian survivors, my immediate reaction was: they are the experts, they will have to tell us what kind of film we should do. This evolved fairly quickly in the participatory approach of WWU2K. Today I am starting to understand that our work with Cambodian survivors and their courageous example probably influenced my choice of going back to Cambodia to confront my painful past there three years later. Another peculiar aspect of this case is that the crisis I am talking about is not causally related to the work we were doing. Indeed, there is a casual (and as such, very disturbing) connection though between our work and the unexpected tragic turn my/our life $^{29}$ took while we were working there. There is nothing other than the specific 'space' where this all happened - Cambodia, curiously enough, the place where I started, almost playing, to do documentaries ${ }^{30}$ many years ago, a beautiful wounded country where almost everywhere the gorgeous green and the marvellous temples still smell of blood and horror. It will take many decades to cleanse the country of the traces of the Khmer Rouge delirium.

Cambodia is a place where accident and causality may have or assume an invisible but touchable bond. 


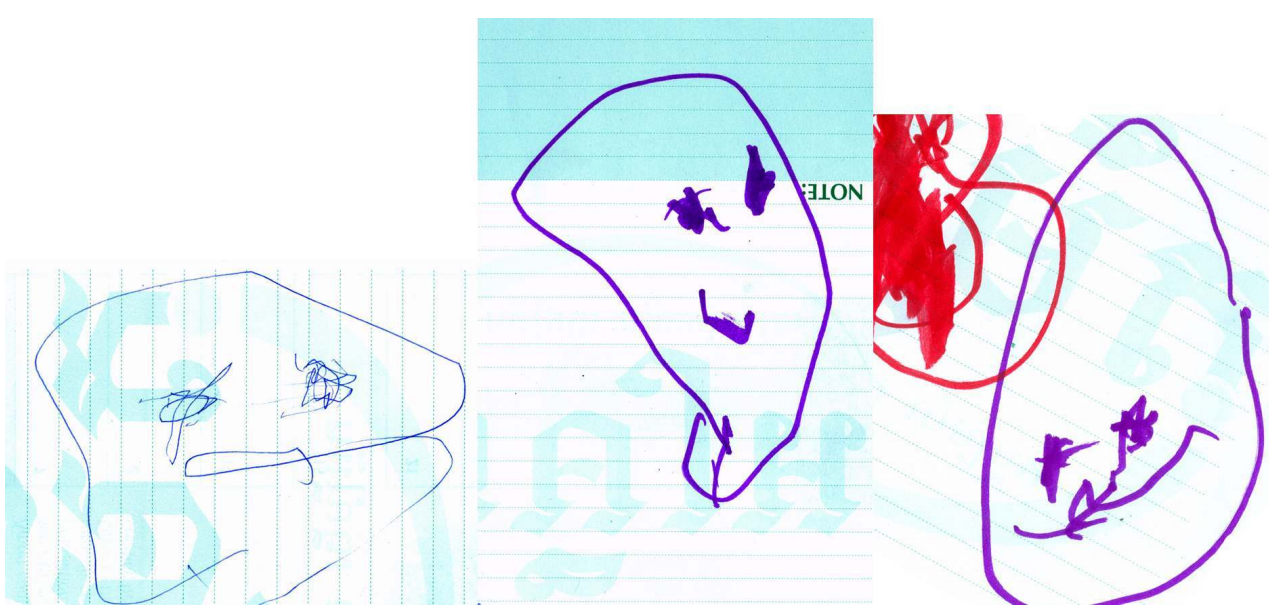

During our Cambodian stay Anouk was drawing continuously. She was 2 and a half, so it pretty surprised us as she came out with a series of faces, some creepy, some funny, some sinister, which reminded us of ghosts.

Drawings by Anouk PJ (2009)

I don't believe in evil spirits, but in 2008 in Psah Orussey, one of the liveliest local markets in Phnom Penh, I found a little book for children that I used to read to my daughter Anouk back then. It tells the story of a man fighting against an evil spirit, a female spirit of course ${ }^{31}$. In the tale the dead woman had long ruffled black hair, was dressed in black to merge herself into the night, and used to kill every man passing by... I'm not sure I remember this right, but the more I think of it the more clearly I remember that she killed every man passing by that one bridge at night. Jens died falling from a bridge at night. It was dark and slippery, it was the beginning of the rainy season and it had been raining all day. The bridge was neither indicated with a sign nor protected. Most probably a car with undipped headlights came at high speed and he jumped aside, lost his balance and fell. It was not high, there was not much water under the bridge, but there was enough to take your breath away if you fell unconscious, enough to kill you silently in few centimetres of water and few minutes.

My dear

My heart is going to take fresh air

Otherwise how could I find words

and tell the miserable details

of your death a death in the night a death in the water a death an horrible death a death black like the night that night how could I

My heart has gone for a walk otherwise I could not say I could not stay but dye with you

Bye heart bye

The story of the ghost woman is not a fairy tale; it is part of local beliefs in Cambodia. And for some people there, what happened to us was, in fact, not simply a terrible accident.

\section{The Land of the Spirits}




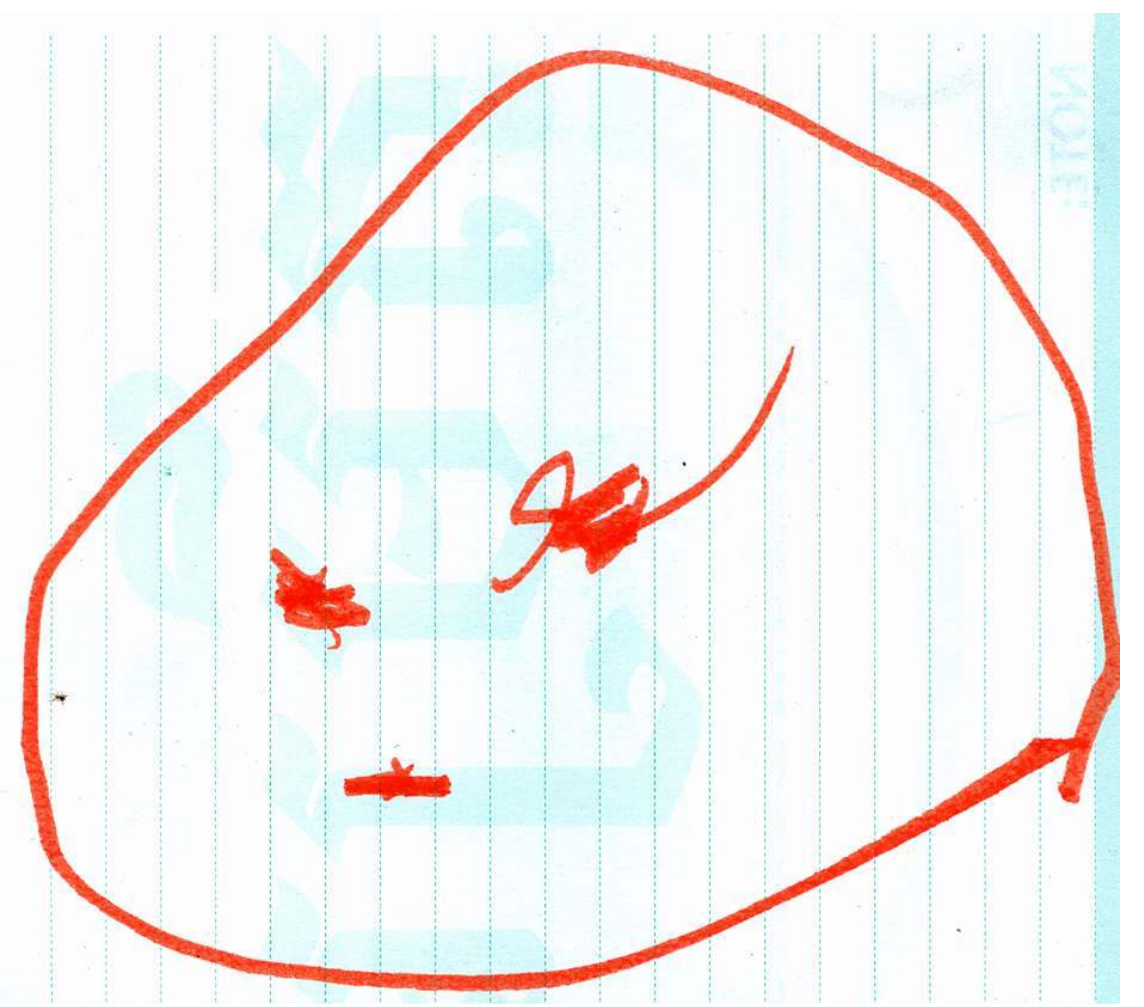

Drawing by Anouk PJ (2009)

And I often look for you around,

Hoping your spirit will come out

with your sky-blue jacket

I stay there staring at the silence

in the mirror

Back in the corner of my left eye

something seems to move - a cat?

An invisible friendly ghost? O Ghosts,

Ghosts, come with smiles

Come to me

The majority of Cambodians practice Buddhism, as the numerous wats that can be seen everywhere make clear. Theravada Buddhism was brought from Sri Lanka in the $14^{\text {th }}$ century when the Angkorian era (9-13 $3^{\text {th }}$ century CE) slowly but surely was "starting to disintegrate militarily, economically and socially. Until then Hinduism was the major religion coexisting with the old animistic religion" (Eliezer 2002: 1). This is the source of the strong Cambodian spirit beliefs. Ancient and new religions have coexisted till today, as the shrine-houses erected in every imaginable corner of the country clearly show. In front of the house they make offerings to the spirits of the family ancestors, that always include pleasures to satisfy the stomach and the eye, such as water or wine, bananas, sweets, and beautiful ceremonial flowers ${ }^{32}$ : "In Cambodia, it is recognized that healthy grieving involves maintaining a good relationship with the dead and perhaps assisting the dead towards rebirth." (Agger 2015: 8). It is also usual to find makeshift shrines to Neak $\mathrm{Ta}$, the local spirits, among trees, on riverbanks, at significant spots along major 
roads, in the yards of public offices and schools, at the entrances of the wats and so on ${ }^{33}$. "Neak Ta are wherever people feel a particular power or beauty" (Sloan 2006) ${ }^{34}$. Most Cambodians believe that spirits are part of this world, as are devadas (angels) and kamauch (ghosts). Ghosts can be a great source of information; they can confer supernatural or even ancestral power. But they can also bring spells in form of illness, incidents and back luck, if not properly respected. They "require people to regularly maintain positive communication with them and carry out ceremonies at particular places where they dwell" (Keating 2012) ${ }^{35}$. This seems to be connected with the strong merit-making principles of Cambodian Buddhism. Even if you are not Buddhist you can feel the law of karma as an imminent presence in this "incredibly and inherently spiritual" (Eliezer 2002: 1) country. I understand karma as the 'destiny' of your soul, something that you forge or ruin in this life for the next one, resulting in a mix of fatalism, as a person can't change her situation and should be resigned to her destiny, and determinism. In fact karma is also considered to be 'action'. By doing good in this life everybody can determine or at least influence step-by-step the cycle of birth, death and rebirth in continual suffering (dukkha), climbing through merit towards nirvana, the state of happiness or non-existence, and the ultimate escape from the cycle of karma.

When we were working in Cambodia I felt nervous every time I read or remembered that the Khmer Rouge liberated/invaded Phnom Penh and evacuated the population for what became the most radical and violent 'agrarianisation' of an entire country ever seen on 17 April 1975. Jens was born in 1983, some years after the Khmer Rouge were driven by the Vietnamese, themselves liberators and conquerors, back into the forests along the Thai border. But Jens was born on this damned 17 April, and although we never articulated this because we did not believe in silly coincidences, I definitely felt nervous. We were fighting against the bloody ghosts of this recent past, seemingly going against the Buddhist belief, or tendency, or what in my opinion I came to think of as a form of political exploitation of Buddhism: do not look back, do not move (or remove, I'd add polemically) the thorn in the wound; instead smile and look further, forget. Forget all the crimes committed by the hundreds and hundreds of small Khmer Rouge cadres, who are probably your neighbours today; forget especially the 'big fish', who are more than likely your governors today. We were motivated and proud to go against this stream with our project and with our work, against the sheer impunity and silence throughout the testimony and the engagement of our protagonists. During our time there we met every kind of adversity possible in this kind of work: initial misunderstandings with colleagues, especially cultural misunderstanding regarding my simultaneous roles as film director and mother ${ }^{36}$, the least serious problem which we overcame over time, strategic problems and, unfortunately, financial conflicts with the leader of the Cambodian NGO who was administrating the project. Jens became unwell with three different and fairly serious illnesses which were diagnosed one after the other, reducing the effectiveness of the prescribed remedies. We originally planned three to four months in Cambodia and ended up staying for seven months and had not even finished by then. This is maybe the least surprising surprise, because four months was never going to be long enough for such a demanding project to be effective. But before we arrived our plan had been to do some PV with the survivors in the countryside, and not to work on such a complex and multilayered film project.

In May 2012 during our preparatory meeting for the Symposium about PV in Gottingen ${ }^{37}$, my colleague Nou Va told me and the anthropologist Caroline Bennet that the villagers 
were quite upset with him and the other Cambodian staff, as we had met there some months before and talked about Jens's fate for the first time. Thinking back, they said, we should have initiated our work and the filming in the village with a ceremony for the spirits, for the dead or at least for the monks in the pagoda ${ }^{38}$. I was dismayed to hear this - and to hear it months after we had been in the village together. Why had Va not told me while we were in Thnol Lok ${ }^{39}$ I could not ignore the inner voice which troubled me most when I heard this story, which was screaming at me: 'Why didn't we respect these traditions, beliefs, or whatever they are called? Why?'

Va does not believe in spirits but sincerely respects these practices; he was always very sensitive to similar issues, and guided us in religious and cultural matters. His expression and the tone of his voice as he was telling us about this episode showed clearly the extent to which he had been personally affected by the critique aimed at him by the other Cambodians.

A few seconds later I realized that, as with Va, these beliefs did not match those of Jens or myself. And I certainly do not think rationally that this caused any harm, or that Jens death could be explained by similar dark thoughts. I don't. I don't. I don' I don I do I

One thing I know: if anybody, the villagers, the Cambodian staff, had told us of this practice ${ }^{40}$, if $\mathrm{Va}$ had thought of it at the time - it was simply another senseless casualty that he forgot-I would, Jens would have definitely said yes, let's do it, of course, out of respect for the country which hosted us. And because we felt it was a dangerous world, a dangerous mine field that we were walking through.

Fatal accidents, like harmless accidents in life, are simply the result of senseless chances. Even though some seem to come together, so precisely, so accurately, so determinedly, that we may happen to stare the rest of our lives at them. That every time we think of it we have to wonder how it came about.

Lost shoes

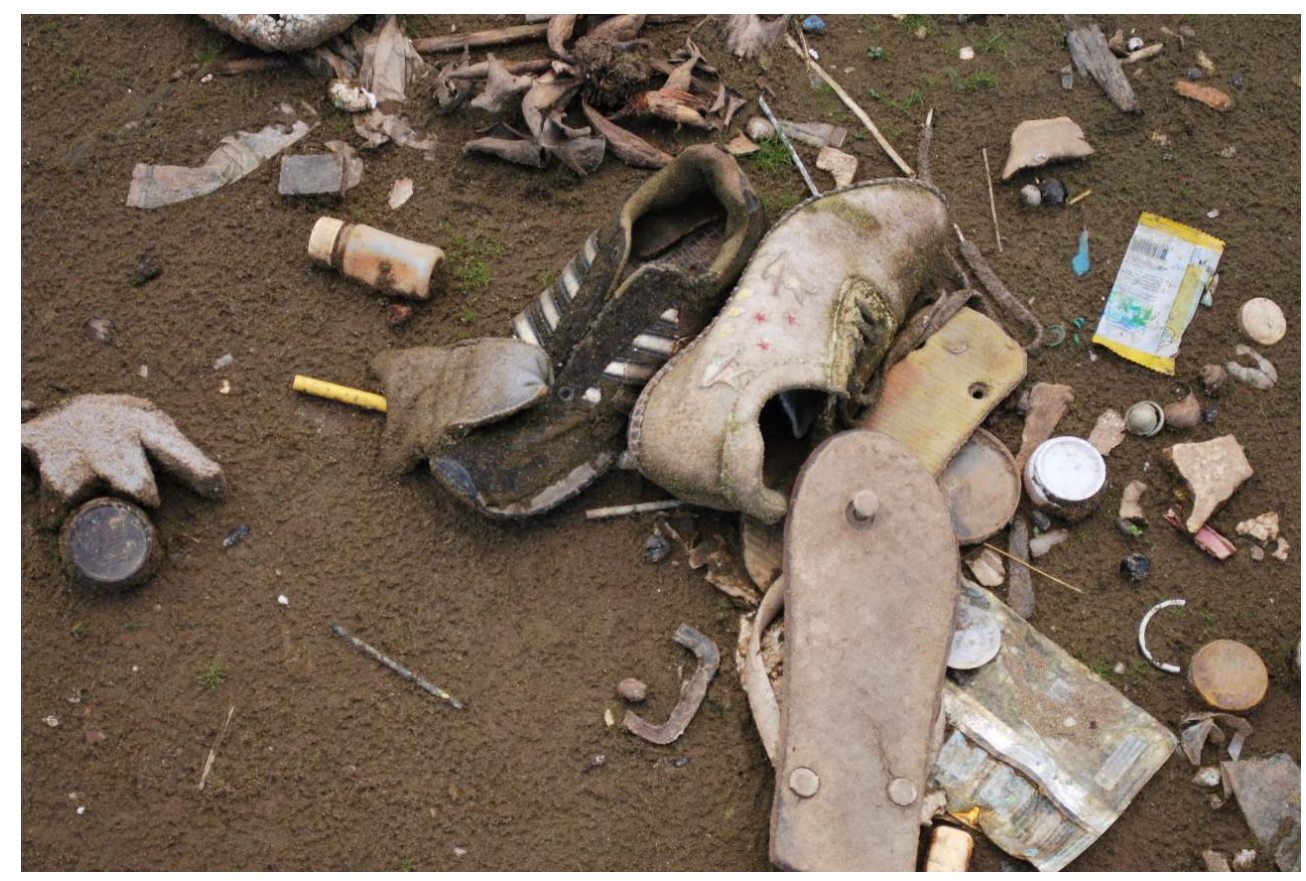

Where are you going, you lovely shoe?

Photo by Jens Joester (2009) 


\section{Disruptive Writing}

I often talk alone

loud

especially at night

when everybody is asleep

or dead

Everything I have written up to this point hides a very fragile balance indeed.

I am approaching ethnography as a traumatized person. I recently discovered autoethnography as a relatively new and controversial research method, which has been often connected with feminist writing. Carolyn Ellis, a well-known auto-ethnographer, defines it as "research, writing, story and method that connect the autobiographical and personal to the cultural, social and political" (Ellis 2004: xix)). With my background as a woman filmmaker working closely with her protagonists and experimenting with participatory methods, I immediately felt sympathy for an approach that seems to reject deep-rooted binary oppositions between objectivity and subjectivity, between process and product, self and others, art and science, and the personal and the political (Ellingson and Ellis 2008: 450-459). This is exactly what I was looking for as I started to conceive this article: to find a personal, poetic, autobiographic language in order to talk about the intersections that I experienced between the personal and the political in Cambodia. At that point I did not know that it was an ethnographic genre, and one that has been strongly critiqued for its self referentiality, self indulgence, and partiality, among other things ${ }^{41}$. Indeed, I was not convinced by every auto-ethnographic text I read during the preliminary research, but some touched my inner feelings, others inspired and moved me. I don't support the entire critique, though I see the dangers in the method. How can I not refer to myself if I want to be self-reflexive? How can I not be self indulgent and partial if I want to tell such a partial painful story like the one I'm going to tell, my story? Willing or not, it seems like what I'm trying to do is auto-ethnography, as it hides the ambition of using art for research as well as research for art, and compels a reflexive, vulnerable multi-layered text open to emotion and uncertainty ${ }^{42}$.

There are parts of this story, the most personal and emotional parts, that I can only express through poetry. That's how I came to counterpoint the storytelling in these pages with those verses, as if they were citations, like the citations I make from my reading, like this one: "I know that trauma leaves me lost and speechless, and that my memory is invested in safety, not remembering. What breaks my heart also breaks my tongue." (Tamas 2009: 3). Sophie Tamas questions the concept of knowledge production in itself, when it aims to transform loss and trauma into something "personally and socially useful and meaningful". She wisely warns against telling one's own broken story in tidy, 'collected tones', as if everything was over, as if we'd have already recovered, as if it would be possible at all, to recover from trauma. Of course she speaks from a western perception of trauma which may not match the perception of those who lived through the Khmer Rouge and other such horrors. However, I found some comfort in her reflections. I believe that trauma and grief are not maladies that you can recover from. Rather, they are matters of fact, and eventually stages in our lives. They may change our lives, our language, and the way we perceive the world. Our voice may be as broken as the experience we're trying to come to terms with, and just as insane. Testimony, especially 
trauma testimony, which is so essential in therapy literature and often described as 'performative ${ }^{43}$, is not possible from a distance and not possible without compromising oneself. It is "affective and embodied, and often doesn't make sense. It is that messy text that we talk about in our tidy ways" (Tamas 2009: 3).

Kakkda and a piece of Jens

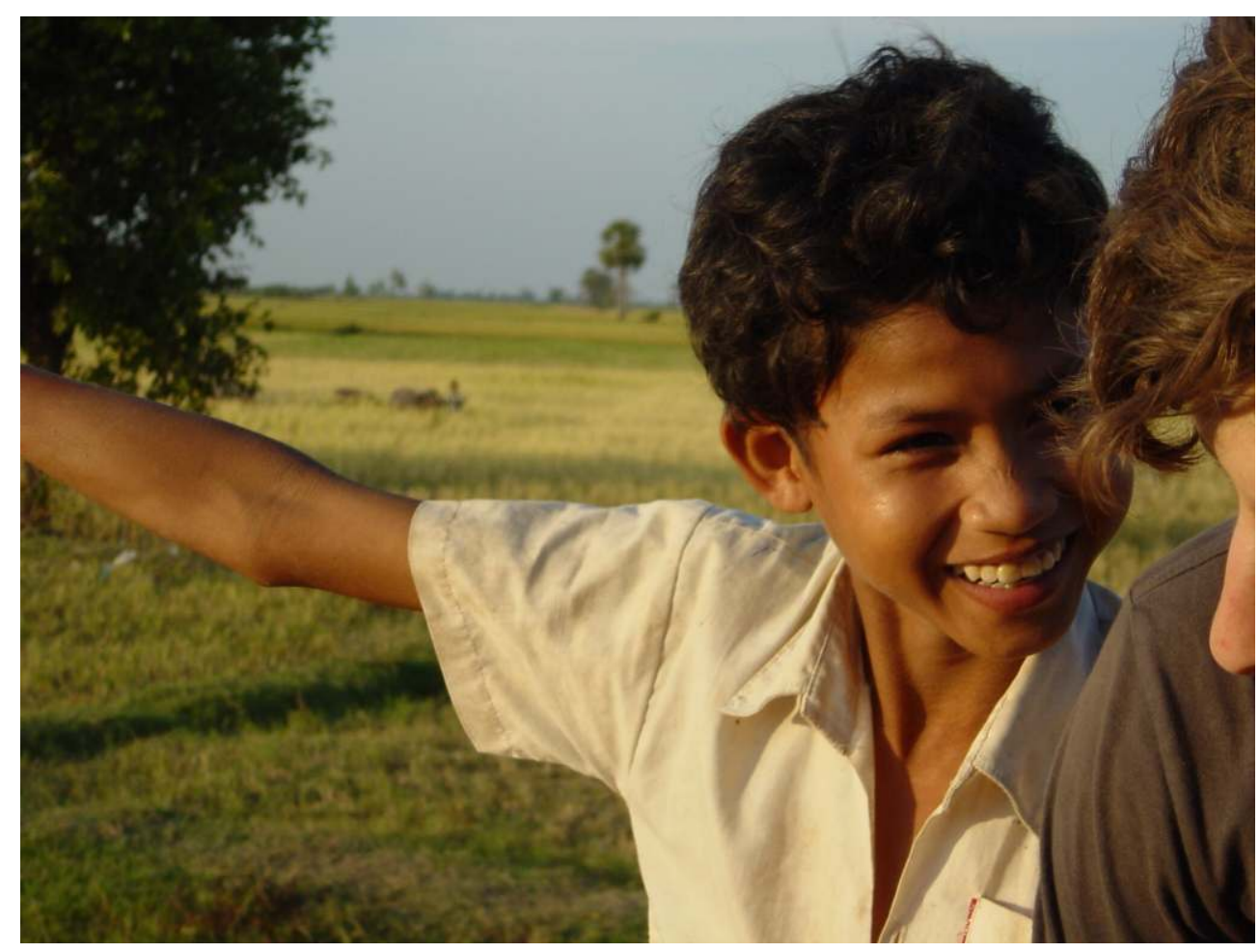

Jens, like most people accustomed to stay behind the camera, did not like being photographed. We have very few photos of him indeed, many with only a nose - or a smile

Photo by Julian Poluda (2008)

So - can I really talk about my personal loss and the following mourning process, not concluded, never to be concluded? Can I ever achieve the intersection between other people's stories of loss and my personal loss without becoming insane? In other words, can I bear witness, without breaking my heart? Without irritating the reader? What if I start to scream: 'Why?'

You will never get an answer

You will never finish asking

53 why

it happened

You will ask the moon up there

The water in rivers and seas

Your toenails

walking I front of you

as long

as they'll be walking

you away

Your body 
an infinite source - spring water -

of distilled, slow motion

pain

An infinite source does not stop

Any time you open up your body

the fluid flows out and

aporates

Didn't you notice a certain quality of the air around me?

Didn't you?

What does it change, how does this language affect my writing, my testimony, my memories? Helen Cixous says, "writing is writing what you cannot know before you have written it..." ${ }^{44}$, so there is hope. One day I may know.

Cambodian Landscape

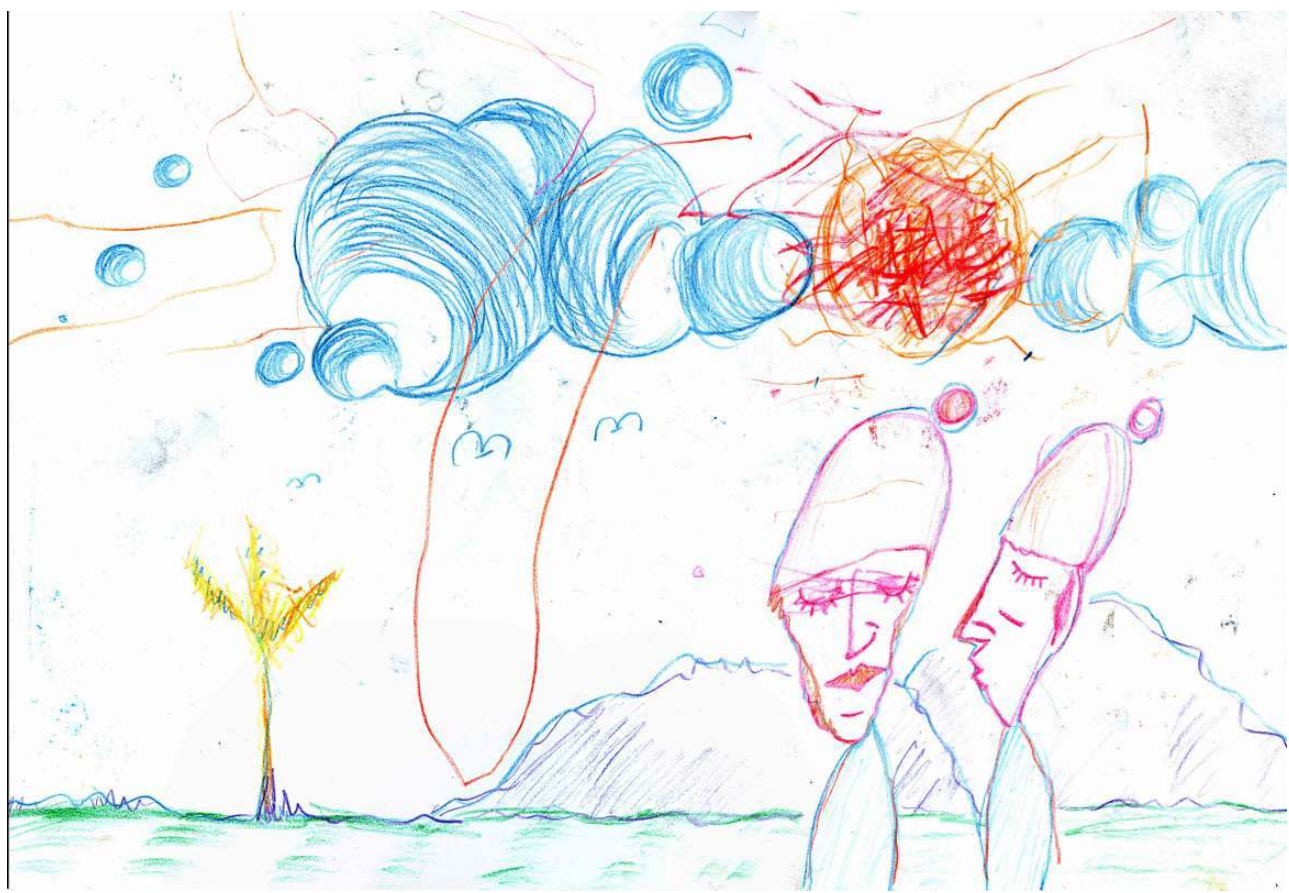

Drawing by Jens Joester (2008)

End of first part.

\section{BIBLIOGRAPHY}




\section{Books and Papers}

Agger Inger,. 2015. Calming the mind: Healing after mass atrocity in Cambodia, Transcult Psychiatry 2015, Feb 4.0 (0):1 - 18. http://tps.sagepub.com/content/ early/2015/02/04/1363461514568336.long

Agger, Inger, Igreja Victor, Kiehle Rachel, Polatin Peter. 2012. Testimony ceremonies in Asia: Integrating spirituality in testimonial therapy for torture survivors in India, Sri Lanka, Cambodia, and the Philippines, Transcult Psychiatry 2012, Jul; 49 (3-4): 568-589 http:// www.ncbi.nlm.nih.gov/pmc/articles/PMC3472560/

Barrette, Catherine. 2011. Trauma and Recovering through Art: The Construction of Self, Trauma imprints: Performance, art, literature and theoretical practice. C. Barrette, B. Haylock and D. Mortimer, eds. Pp. 3-11. Cambridge, England: Inter-Disciplinary Press.

Behar, Ruth. 1996. The Vulnerable Observer. Anthropology That Breaks Your Heart. Beacon Press, Boston.

Behar, Ruth. 2003. Ethnography and the Book That Was Lost. Ethnography, March 2003, Vol.4.1, SAGE Journals.

Boni, Cesare. 2009 (2001). Dove va l'anima dopo la morte. Torino, Edizioni Amrita.

Bray, Peter and Oliver Bray. 2011. Fathers and Sons: An Autoethnographic Case Study of Bereavement and Trauma. In Trauma imprints: Performance, art, literature and theoretical practice. C. Barrette, B. Haylock and D. Mortimer, eds. Pp. 13-23. Cambridge, England: Inter-Disciplinary Press.

Caruth, Cathy. ed. 1995. Trauma. Explorations in Memory. Baltimore, John Hopkins University Press.

Chhim, S. 2013. Baksbat (broken courage): A trauma-based cultural syndrome in Cambodia. Medical Anthropology, 32(2), 160-173.

Crickmay Chris and Miranda Tufnell. 2004. $2^{\text {nd }}$ Ed. 2008. A Widening Field: Journeys in Body and Imagination. Alton, Hampshire: Dance Books.

Croisy, Sophie. 2006. Re-imagining Healing after Trauma: Leslie Marmon Silko and Judith Butler Writing against the War of Cultures. Nebula 3.2-3.

Eisenbruch, Maurice. 1991. From Post-Traumatic Stress Disorder to Cultural Bereavement: Diagnosis of Southeast Asian Refugees. Social Science \& Medicine 33(6): 673-680.

Eliezer, Inpa. 2002. The Buddhism of Cambodia. CMS Australia Mission Essays http:// www.cms.org.au/_resources/The-Buddhism-of-Cambodia/1b83e330-

a1b4-1812-9165-99796261de15.

Ellis, Carolyn. 2003. Grave Tending: With Mom at the Cemetery. Forum Qualitative Sozialforschung / Forum: Qualitative Social Research. 4(2), Art.28 http://www.qualitative-research.net/index.php/ fqs/article/view/701/1520.

Ellis, Carolyn. 2004. The Ethnographic I: A Methodological Novel about Autoethnography. Walnut Creek, CA, Alta Mira Press.

Ellis, Carolyn, Adams, Tony E. and Bochner, Arthur P. 2011. Autoethnography: An Overview, Forum Qualitative Sozialforschung / Forum: Qualitative Social Research. 12(1), Art.10. 
Ellingson, Laura L., and Ellis, Carolyn. 2008. Autoethnography as contructionist project. In J. A. Holstein and J. F. Gubrium (Eds.), Handbook of Contructionist Research (pp.445 -466). New York, Guilford Press.

Felman, Shoshana. 1995. Education and crisis, or the vicissitudes of teaching. In: Cathy Caruth (Ed.), Trauma. Explorations in Memory (pp. 13 - 60). Baltimore, John Hopkins University Press

Freud, S. and Rickman, J. 1957. A General Selection of the Works of Sigmund Freud. New York, Liveright.

Guillou, Anne Y. 2012. An alternative memory of the Khmer Rouge genocide: The dead of the mass graves and the land guardian spirits (neak ta). South East Asia Research 20(2): 207-226.

Hansen, Leshia. 2014. Mental Health Trauma among Cambodians and Cambodian Refugees after the Pol Pot Regime Conflict: A Literature Review. Institute for Global and International Studies. George Washington University, Washington.

Kachler, Roland. 2012 (2005). Meine Trauer wird dich finden. Ein neuer Ansatz in der Trauerarbeit. Freibug, Kreuz Verlag.

Keating, Neal. 2012. Spirits of the Forest: Cambodia's Kuy People Practice Spirit-Based Conservation. Cultural Survival CSQ 36(2) (Summer 2012) 40 years of Advocacy http:// www.culturalsurvival.org/publications/cultural-survival-quarterly/spirits-forest-cambodiaskuy-people-practice-spirit-based

Kilby, Jane. 2002. The Writing of Trauma: Trauma Theory And The Liberty Of Reading. New Formations: a Journal of Culture/Theory/Politics 47: 217-230.

Lather, Patti. 2007. Getting Lost: Feminist Efforts towards a Double(d) Science. Albany, State Universitiy of New York.

Levine, Peter. 1997. Waking the Tiger: Healing Trauma. The innate Capacity to Transform Overwhelming Experiences. Berkeley, CA, North Atlantic Books.

Mallon, Brenda. 2008. Dying, Death and Grief. London: SAGE Publications.

Manning, Debra. 2007. Auto/ethnography: A journey of self/indulgence. Paper presented at the AARE Annual Conference, Fremantie http://www.aare.edu.au/publications-database.php/5441/ auto-ethnography-a-journey-of-self-indulgence

Maynard, Kent and Cahnmann-Taylor, Melisa. 2010. Anthropology at the Edge of Words: Where Poetry and Ethnography Meet. Anthropology and Humanism. Vol. 35, Issues 1: 2-19.

Neville-Jan, Ann. 2004. Selling your Soul to the Devil: An Autoethnography of Pain, Pleasure and the Quest for a Child. Disability \& Society 19(2): 113-127.

Somasundaram, Daya J., Willem A.C.M.van de Put, Maurice Eisenbruch, and Joop T.V.M. de Jong. 1999. Starting Mental Health Services in Cambodia. Social Science \& Medicine 48.

Sloan, Bronwyn. 2006. Sage and Spirit. Phnom Penh Perspective October 2006 http:// www.talesofasia.com/cambodia-bronwyn-oct06.htm

Tamas, Sophie. 2009. Writing and Righting Trauma: Troubling the Autoethnographic Voice. Forum Qualitative Sozialforschung / Forum: Qualitative Social Research. 10(1), Art. 22.

Whitehead, Anne. 2004. Trauma Fiction. Edinburgh, Edinburgh University Press.

Films

Agger, Inger and Sofie Rørdam (dir.) 2013. Justice and Healing in Cambodia. $32 \mathrm{~min}$. https:// www.youtube.com/watch?v=X7_or7pU-ec 
Pugliese, Ella, Nou Va, and the Villagers of Thnol Lok, dir. 2011. We Want (U) To Know. KID (production). $54 \mathrm{~min}$. TRAILER: https://www.youtube.com/watch?v=SY0D8nugnrY

Pugliese, Ella and Niklas Luhmann (dir.) 2002. Playing Cambodia. Luhmann - Pugliese (production). 38 min. https://vimeo.com/111621869

Websites

http://www.ciu-ascona.org/a-eng/Activities/Past.html

http://en.wikipedia.org/wiki/Autoethnography

http://en.wikipedia.org/wiki/Catharsis

http://www.gieff.de/abstracts-and-biographies/articles/ella-pugliese-and-nou-va.html

http://www.gieff.de/discussions/articles/ella-pugiese-and-nou-va-we-want-u-to-know.html

http://periferiesurbanes.org/?lang=en\&s=cambodia

http://primal-page.com/cathar.htm

http://www.creativepsychotherapy.info/dramatherapy-and-psychodrama/

http://www.culturalsurvival.org/publications/cultural-survival-quarterly/spirits-forestcambodias-kuy-people-practice-spirit-based

http://www.we-want-u-to-know.com/content/participatory-approach

https://www.facebook.com/WWU2K

http://www.cinemambiente.it//?action=film\&id=1113

http://www.talesofasia.com/cambodia-bronwyn-oct06.htm

http://www.vivo.org/resources/net/index_eng.html

\section{NOTES}

1. See also the legacy of Mallarmé and Celan for the theme of poetry and testimony, and the value and significance of trauma testimony (Felman 1995).

2. At that time in Phnom Penh during preparatory meetings with the Cambodian and International NGOs' staff and in unofficial discussions I often heard that after 30 years it was time 'to break the silence'. This perception of a long period of silence was very general. Even when I came to Cambodia for the first time in 2000, I heard many Cambodians talking about the long period of silence, which might slowly come to an end: Pol Pot, Brother Nr, one of the Khmer Rouge who reportedly died in 1998 although the facts of his death had not been established, and the Khmer Rouge may regain power. Nevertheless, below the surface nevertheless, Cambodian people were elaborating their ways to cope with the past, as recent studies show us: "the Cambodians have not remained silent, unconcerned or reluctant to try the Khmer Rouge leaders, but had instead developed, decades before the trial, their own 'relief device' from social suffering and their own sophisticated 'memory device' interlinked with the traditional Khmer religious system. (Guillou 2012: 212).

3. See section 4: Situating We Want (U) to Know - our participatory approach

4. Guillou 2012: 212.

5. The Freudian definition of 'psychic traumata' suits this first period of intense suffering very well: a psychic deformation and symbolic wound where the usual way of dealing with the reality and processing experiences fails. (Freud and Rickman 1957: 6-7). 
6. Short for We Want (U) to Know.

7. "In Unclaimed Experience Cathy Caruth writes, one's own trauma is tied up with the trauma of another... trauma may lead, therefore, to the encounter with another, through the very possibility and surprise of listening to another's wound"' (Croisy 2006: 108)

8. I owe the inspiration for the structure - and the naming - of these first sections to Ann Neville-Jan (2004), where she situates herself and the specificity of her search in order to make her position clear.

9. At the time I was doing a Master in Intercultural Mediation at the University of Roma Tre and chose audio-visual Anthropology as my main focus.

10. The first version of the film is 90 minutes long and shows three different kinds of stories. The new version is shorter at 54 minutes and focuses on the participatory process in Thnol Lok. This is the film I discuss in the following pages.

11. http://www.we-want-u-to-know.com/content/participatory-approach

12. In 2012 I took part in the Symposium at Göttingen, 'Participatory - What does it mean? Participatory Cinema - Participatory Video under Consideration', and discussed with anthropologists, social workers and filmmakers the pros and cons of PV. It was a rich and intense exchange as well as an opportunity to clarify aims and motivations and enlarge the prospective about this controversial method. See http://www.gieff.de/abstracts-and-biographies/articles/ ella-pugliese-and-nou-va.html and http://www.gieff.de/discussions/articles/ella-pugiese-andnou-va-we-want-u-to-know.html

13. Two persons enjoyed the camera filming so much that they became our 'cameramen': Mr.Sam Ath, quickly promoted to 'village cameraman', and the young Kakkda, our 'cameraman to be', around 15 years old at the time. Both showed passionate commitment to the project till the end.

14. Defined a 'classical' participatory video by anthropologist Stefano Portelli on Periferies Urbanes (http://periferiesurbanes.org/?lang=en\&s=cambodia), WWU2K has been shown hundreds of times in Cambodia and it continues to gain recognition internationally, as documented on the film Facebook page: https://www.facebook.com/WWU2K.

15. The typical Cambodian scarf. The Khmer Rouge were using almost exclusively red and white ones.

16. "Trauma, with its psychic violence and sudden disruption, makes us suffer from lack of wholeness", another happy definition, which follows the inspiring explanation: "To heal, in its etymological meaning, is to make whole" (Barrette 2011:3).

17. Eisenbruch (1991) suggests that it is better to use the term 'cultural bereavement' instead of PTSD, post-traumatic stress disorder, in discussing the distress experienced by Cambodian refugees: "the person or group continues to live in the past, is visited by supernatural forces, irons the past while asleep or awake (...) this is not of itself a disease but an understandable response to the catastrophic loss of social structure and culture" (1991: 2). This response may be "normal, even constructive, existential" (1991: 1).

18. "An article by Chhim (2013) explores the Cambodian phenomenon of baksbat, and its relation to PTSD. Chhim concludes that baksbat includes different symptoms from PTSD and therefore this may be classified as a unique Cambodian-based trauma system. This is another example of the shift to understanding trauma as it fits with the cultural framework of the Khmer people. It adds to the development of the shift in understanding PTSD as an overarching psychiatric experience to one that is bound to the culture of the people who experience it." (Hansen, 2014: 4).

19. "Western practitioners (...) still have much to learn by paying close attention to the way in which survivors themselves formulate and seek to address their distress". (Agger 2015: 13). This is indeed what we were aiming at through our inclusive approach. Again Agger (2015: 2): “(..) some of the recent work in the field of transcultural psychology and psychiatry on survivors of the Khmer Rouge regime (...) argues for greater cultural sensitivity in approaches to their mental 
health and is critical of "Euro- Western universalized semiotic of sufferings." (Kidron 2012: 723, cited in Agger 2015: )" Like Eisenbruch and Chhim, Agger stresses that "the mental effects of trauma may be experiences and expressed in markedly different ways in different cultural contexts and that much may be learnt by also exploring what cultural tools may be available to address posttraumatic distress" (2015: 2). As typical occurring symptoms she lists "'thinking too much" (Khmer kut caraeun), which "may lead to headaches, dizziness, 'wind attacks', depletion of bodily energy, heart weakness, and even 'overheating of the brain' (memory loss, insanity)" and "recurrent, disturbing dreams about loved ones who dies untimely or violent deaths during the regime" (2015: 3-4), and investigates widely "Cambodian methods for calming the mind", like meditation and making merit for the deceased.

20. "It would also be relevant to explore in more depth how Western notions of psychological health and methods for achieving it are being transposed into the Asian context, possibly giving rise to innovative, hybrid discourses and therapeutic methods." (Agger 2015: 12). In the same way Western cognitive methods have been inspired by Asian practices and combine elements of mindfulness and meditation within the therapy.

21. This remained a key question throughout the whole process. The psychologists from TPO supported the villagers who did experience moments of emotional pain, offering them a space to talk separately and express their feelings. Two villagers accepted this offer and seemed to benefit from it. We talked about that as staff and tried to evaluate the consequences for the participants during the work. At the time we had the impression that people progressed well with this direct confrontation of the past, probably because they consciously decided, each one for her/himself, if and especially in which forms they would take part in the project - from re-enacting, to leading the scenes, to simply drawing and bringing the own memories in experience, to just watching. The spontaneity of the process gave the participants a fairly high degree of freedom in the way and intensity they engaged in it, helping them to stay on what we could see was the safe side. However you can assess consequences only in the long term. See the section 'The case of Grandma Nhey' for more details.

22. The workshop was organized by the Centro Incontri Umani Foundation, in co-operation with the Göttingen International Ethnographic Film Festival. See: http://www.ciu-ascona.org/a-eng/ Activities/Past.html

23. As mourning seems to be a 'non linear' inner process which mostly comes in unexpected waves of despair, lack of sense, physical weakness when not temporary inability to function, it is not surprising at all that I was able to work on this project and finalize it 'in waves'. In the summer after the events I finalized the DVD design which Jens had initiated with Gregor Matuschek, our producer and dear friend, in the autumn I organized a major Premiere event in Berlin, in the winter of 2010 I gave some seminars in High Schools and Universities about WWU2K with Leah Roth-Howe, who had been with us on the set, and the following summer I worked on the short version of the film with the editor Max Kähni, a colleague and good friend of Jens, which we completed in 2011, and so on. Noticeable in this short list is the fundamental help of friends and colleagues, particularly the figures of Jens's friends who still have a major role in our life.

24. Here the definition of VIVO about narrative exposure therapy: "a treatment for traumaspectrum disorders in survivors of multiple and complex trauma. (...) fragmentary memories are transformed into a coherent narrative structure: a testimony. This practice enables the processing of painful emotions and the construction of clear contingencies of dangerous and safe conditions, generally leading to significant emotional recovery. From: http://www.vivo.org/ resources/net/index_eng.html

25. See: http://en.wikipedia.org/wiki/Catharsis, http://primal-page.com/cathar.htm, http:// www.creativepsychotherapy.info/dramatherapy-and-psychodrama/ 
26. On auto-ethnography: Ellis 2003, Ellis, Adams amd Bochner 2011. On trauma: Caruth 1995, Whitehead 2004, Boni 2009, Kachler 2012, Kilby 2002. On performative writing: Crickmay and Tufnell 2004, and connected to trauma: Bray 2011, Barrette 2011.

27. Her documentary 'Justice and Healing in Cambodia' is a good example of the benefits of testimony therapy. See also: Agger 2015, and Agger et al., 2012.

28. Foreword by Phyllis R. Silverman in Mallon 2008: ix.

29. As it is still very hard for me to define boundaries between the different identities involved in this story, I will switch from 'I' to 'we', from 'me' to 'us', following my perception of the language in each particular phrase. It may look arbitrary, but I'm pretty sure that it hides some sense - and I am a little confident that it may even help to reveal some deeper sense while reading.

30. Playing Cambodia (38 minutes, Italy, 2002) Cambodia, November 2000: after about a thirty year-long civil war and more than three million victims, peace seems to have come back again, but two years after his death, the name of Pol Pot resounds in all speeches and individual stories. And yet in this land still plagued by so many horrors, people play, at any time, at each corner, in the country as well as in town, often for money. Under Pol Pot's heel, death had wiped everything away, not just the playing games, but also schools, medicines, religion. Today the farmers, after a hard working season, can gamble away all their harvest in a cockfight, while boys play bowling without thinking that those grey and hollow balls were used to blast people out. In this journey we are driven by five characters. Their voices and smiling faces show the complexity of reality to the foreigner, while the games are the reading clue, the fil rouge unwinding along the places, along the memories, narrating a desperate and wild [SIC] world. FROM: http:// www.cinemambiente.it//?action=film\&id=1113

31. As for Cambodia, "It is traditionally accepted that women should carry the consequences of 'bad actions' of others (...). AIDS is seen as given by women, and received by men. The Khmer saying 'pros chea meas teuk dop...' (which is understood to mean men are gold, women are cloth) is an apt illustration of the position that women take in society." (Somasundaram et al. 1999: 1040). 32. Spirits are strongly believed to get hungry. If they are not feed at the proper time, for example during Pchum Boeun, the feast of the dead, they can become extremely angry, with terrible consequences for the living.

33. In 2014 I discovered the fascinating research of French anthropologist Anne Yvonne Guillou, who has been working in Cambodia for decades. She has investigated the "sophisticated, although unknown, social device set up by the Cambodian peasants in order to express social suffering, but also give local meaning to the genocide." (Guillou 2012: 226). Her analysis focuses on the analogies between Neak Ta and the dead of the Khmer Rouge mass graves: " My hypothesis is that at least some of them are spirits in the process of becoming land guardian spirits. Massive bereavement has been incorporated into the popular religious framework, particularly of the land guardian spirits with whom the dead of the mass graves share many characteristics. This allows a specific relationship between the dead and the living and a specific memory of the genocide consisting of alternatively forgetting and remembering" (Guillou 2012: 226). Although it is mostly accepted that mourning is characterized by waves, in the Western tradition we have a rather linear perception of grief, as our perception of time in general is linear. I see a lot to learn also in the circular perception of time that prevails in most of the Asian cultures. Again, Guillou: "The Khmer system of mourning and memory is not based on a linear principle, which would suppose that suffering and loss would be gradually lessened by the work of time and rituals of death. It is based on a circular principle that could be called 'switch on/ switch off." (Guillou 2012: 218)

34. http://www.talesofasia.com/cambodia-bronwyn-oct06.htm

35. http://www.culturalsurvival.org/publications/cultural-survival-quarterly/spirits-forestcambodias-kuy-people-practice-spirit-based 
36. And space: our daughter Anouk was on and around the stage most of the time, with related advantages, such as gaining the sympathy and empathy of the locals, especially the women, and disadvantages, such as the times where I was organizing one scene and she suddenly needed me, she would demand my attention very loudly and in the end melodramatically, attracting critical and ironic gazes, from my male colleagues especially.

37. See http://www.gieff.de/discussions/articles/ella-pugiese-and-nou-va-we-want-u-toknow.html

38. "(...) the dead are treated as an extension of the moral community of the living and attending to their wellbeing and tranquility is integral to the wellbeing of the living as well." (Agger 2015: 8)

39. This episode emphasizes the big gap in communication so common in Cambodia between locals and internationals working together, mostly due to linguistic and cultural patterns. For example it is not well viewed to interrupt people, especially elderly, when they are speaking, so my collaborators were not able to translate to me while interviewing them. Indeed, it happened various time during the filming in the village in 2008 and again in April 2012, that I I came to know much later or almost by chance something important in my eyes, but maybe less important for my colleagues to tell me. This is a serious problem while working without knowing the local language.

40. Va explained to me later that this applies to any kind of artistic or performance project: films, theatrical performances, exhibitions are usually opened with a ritual offerings to avoid bad spells and a bad atmosphere among participants.

41. "The main critique of autoethnography - and qualitative research in general - comes from the traditional social science methods that emphasize the objectivity of social research" (Wikipedia, article on Autoethnography, p. 5). "As part ethnography, autoethnography is dismissed for social scientific standards as being insufficiently rigorous, theoretical, and analytical, and too aesthetic, emotional, and therapeutic. (...) Furthermore, in using personal experiences, autoethnographers (...) are also navel-gazers (...) self-absorbed narcissists who don't fulfill scholarly obligations of hypothesizing, analyzing and theorizing" Ellis et al 2011: 8. See also: Manning 2007, Auto/ethnography: A journey of self/indulgence, particularly the paragraph 'Critiquing auto/ethnography, pp. 11-12.

42. "My artistic process can be described as coming to terms with my changed sense of self and the construction of my post-traumatic identity" (Barrette 2011: 3). As "a polytrauma survivor and an above-knee amputee" as she defines herself, following a dramatic vehicle accident, she uses visual art in order to "make visible the different fragments of self after trauma" and contribute to a better understanding of loss and resilience in her artwork as well as in her scholarly research. "I believe that an artworking approach based on imagination is effective for comprehending the essence of trauma. (...) Art has an affective reality on people: it creates an impact by touching us through our senses and inciting meaningful changes." (Barrette 2011: 9).

43. "...composed of bit and pieces of a memory that has been overwhelmed by occurrences that have not settled into understanding or remembrance, acts that cannot be construed as knowledge or assimilated into full recognition, events in excess of our frames of reference" (Felman 1995: 16)

44. Cixous 1993, cited in Lather 2007: 4 


\section{ABSTRACTS}

As a filmmaker I worked on trauma, loss and mourning in Cambodia from 2008 to 2009, and made a participatory documentary with survivors of the Khmer Rouge Regime. At this time I too experienced violent death in an immediate and personal way, when my beloved partner was killed in an accident. In this article, drafted after I returned from that first visit, I reflect on this private loss, and attempt to analyse and transform it creatively through a public process in which emotions are re-appropriated.

En tant que cinéaste, j'ai travaillé entre 2008 et 2009, sur les notions de trauma, de perte et de deuil au Cambodge et j'ai réalisé un documentaire participatif avec les survivants au régime Khmer Rouge. Simultanément, j'ai été confrontée personnellement et d'une manière directe à la mort accidentelle de mon partenaire. Dans cet article, esquissé après être revenue de cette première visite, je réfléchis à cette perte personnelle et essaye de l'analyser et de la transformer en créativité grâce à une dynamique publique au cours de laquelle on peut se réapproprier les émotions.

Como cineasta, trabajé sobre el trauma, la pérdida y el duelo en Camboya entre 2008 y 2009 y realicé un documental participativo con supervivientes del régimen de los jemeres rojos. En esa época también viví la muerte violenta de una forma inmediata y personal, cuando mi pareja murió en un accidente. En este artículo, escrito después de volver de esa primera visita, reflexiono sobre esa pérdida privada e intento analizarla y transformarla creativamente a través de un proceso público en el que se recuperan las emociones.

\section{INDEX}

Keywords: Cambodia, auto-ethnography, death, trauma theory, ethnography of loss and mourning, Khmer Rouge

Palabras claves: Cambodia, auto-etnografía, muerte, teoría del trauma, etnografía de la pérdida y del luto, Jemeres rojos

Mots-clés: Cambodge, auto-ethnographie, théorie du trauma, ethnographie de la perte et du deuil, Khmer Rouge

\section{AUTHOR}

\section{ELLA PUGLIESE}

Ella Pugliese (Rome, 1974) has a degree in Languages and a MA in Anthropology of Migration. She lives and works in Berlin as a freelance Author and Filmmaker. In the past years she has collected field experiences in refugee and Roma camps from Naples to Algeria, she has worked for international research institutes dealing with migration issues and she has collaborated with the Department of Performing Arts of the University Roma Tre, as well as with RAI-Sat TV. She has co-directed photographed and edited several documentary projects with an anthropological 
focus.

unaklar@gmail.com 